\title{
BENCH-SCALE Flotation OF Chrysocolla WiTH
}

\section{N-OCTANOHYDROXAMATE}

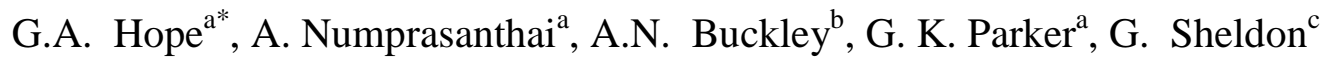

${ }^{a}$ Queensland Micro- and Nanotechnology Centre, Griffith University, Nathan, QLD, 4111, Australia

b. School of Chemistry, University of New South Wales, Sydney, NSW, 2052, Australia

c. AMML, West Gosford, NSW, 2250, Australia

* Corresponding author. Tel.: +617 373 57550; fax: +617 37357773.

E-mail address: g.hope@griffith.edu.au

\begin{abstract}
Raman spectroscopy, Fourier transform infrared (FTIR) spectroscopy, Atomic absorption spectroscopy (AAS) and X-ray Photoelectron spectroscopy (XPS) have been employed to characterise the surface layer and compound formation during the interaction of n-octanohydroxamate with chrysocolla and malachite surfaces. The flotation response of a single mineral chrysocolla - quartz sand sample and mixed chrysocolla - malachite - quartz sand sample using n-octanohydroxamate collector have been investigated. Recoveries of $95 \%$ were achieved in bench-scale flotation testing, with the best $\mathrm{Cu}$ grades achieved at $\mathrm{pH}>9$. Long conditioning times adversely affected flotation performance. Moderate recovery of impurity minerals in the mineral and sand was also observed.
\end{abstract}

Keywords: Mineral processing, Flotation collectors, Oxide ores 


\section{Introduction}

Chrysocolla forms a large potential copper resource that has not been concentrated due to difficulties associated with floating ores containing this mineral. The flotation of this oxide copper mineral is an area of considerable interest to miners and processors where acid leaching is not economic, but disparities in progressing from micro flotation studies through to the processing plant have hindered the practical extraction of copper from the chrysocolla deposits. There have been a number of papers, patents and processes proposed for the flotation of chrysocolla with n-octanohydroxamate, largely based on the results obtained from Hallimond tube experiments with some contact angle data (Aplan and Fuerstenau, 1984; Barbaro et al., 1997; Fuerstenau et al., 2000; Fuerstenau and Pradip, 1984; Herrera-Urbina et al., 2010; Peterson et al., 1965). Unfortunately, these laboratory studies have not been translated into practice. The nature of the chrysocolla structure, porosity and properties have been discussed by Parker et al. (2012).

We have obtained a porous chrysocolla sample from the Clifton district in Arizona in a quantity sufficient for us to undertake kilogram scale, near single mineral, sand extended flotation recovery experiments. This bulk sample has been ground to $85 \%$ passing $100 \mu \mathrm{m}$ to generate a fully liberated chrysocolla and blended with ground sand of similar size profile to provide a synthetic ore sample suitable for bench testing. The same bench-scale flotation cell has been used previously to investigate hydroxamate flotation of blended copper ores of malachite and sulfides from Minto (Lee et al., 2009). In this paper we report the results obtained from bench-scale flotation testing of a chrysocolla-sand mixture as a function of copper content, $\mathrm{pH}$, collector and frother concentrations, conditioning time, $\mathrm{NaSH}$ addition or ammonium hydroxide addition. The nature of the collector-mineral interaction is discussed and the role of the solution potential measured at a platinum electrode is considered.

\section{Experimental methods}

\subsection{Chemicals and materials}

The chrysocolla sample $\left(\mathrm{Cu}_{2-\mathrm{x}} \mathrm{Al}_{\mathrm{x}}(\mathrm{OH})_{4} \mathrm{H}_{2-\mathrm{x}} \mathrm{Si}_{2} \mathrm{O}_{5} \cdot \mathrm{nH}_{2} \mathrm{O}\right.$, with $\mathrm{x}<1$, typical w/w\%; $\mathrm{Si}, 15.2 ; \mathrm{Cu}, 34.4 ; \mathrm{Al}$, 1.4; $\mathrm{Ca}, 0.5 ; \mathrm{Mg}, 0.2$ (RRUFF, 2011)) used in the flotation studies originated from Clifton, Arizona. The 
colour varied from dark blue green to bluish green with some isolated brown impurity visible to the eye. Natural malachite and azurite samples were obtained from the Democratic Republic of Congo and Canada. The flotation collectors, potassium hydrogen n-octanohydroxamate (AM28), $\left(\mathrm{C}_{8} \mathrm{H}_{17} \mathrm{O}_{2} \mathrm{~N}\right)_{2}(\mathrm{H}, \mathrm{K})$ and the commercial variant, $\mathrm{AM} 2\left(\sim 25 \% \mathrm{C}_{8} \mathrm{H}_{17} \mathrm{O}_{2} \mathrm{~N}\right.$ and $25 \% \mathrm{C}_{10} \mathrm{H}_{21} \mathrm{O}_{2} \mathrm{~N}(\mathrm{H}, \mathrm{K}), \sim 50 \%$ water and a minor amount of potassium n-octanoate) were provided by Axis House. Frothers, either methyl isobutyl carbinol (MIBC) or IF50, (from Chemicals and Mining Services Pty Ltd.), were used for the $2.5 \mathrm{~L}$ stirred flotation cell experiments. The $\mathrm{pH}$ was raised when required with $\sim 1 \mathrm{M} \mathrm{NaOH}$ solution. Selected tests were also run with the addition of potassium or ammonium hydroxide. Sodium hydrosulfide hydrate (NaSH), (ACROS Organics) was used to investigate sulfidisation/hydroxamate synergies during flotation plant testing. Flotation in the $2.5 \mathrm{~L}$ stirred cell was undertaken using tap water and compressed air.

A $5 \mathrm{~kg}$ sealed stainless steel laboratory rod mill manufactured by ESSA Australia, model RM 250 x 300, with 10 stainless steel rods was used to grind minerals, ore and sand samples. Chrysocolla was dry ground to approximately $100 \mu \mathrm{m}$ particle size, while malachite ore and the quartz sand samples were wet ground to the same approximate particle size. Particle sizes were measured with a Mastersizer X from Malvern. Sand samples were dried prior to mixing with the chrysocolla (target mineral) and quartz (gangue) components to formulate the selected composition using a Carpeo sample splitter (model SS manufactured by Warman Equipment). Representative samples containing approximately $1 \%$ copper were prepared on a kilogram scale. The quartz-chrysocolla flotation experiments were conducted using a custom laboratory-scale $2.5 \mathrm{~L}$ stirred flotation cell.

\subsection{Analytical techniques}

\subsubsection{Vibrational spectroscopy}

Raman spectra were acquired with a Renishaw System InVia spectrometer. The excitation wavelength was $632.8 \mathrm{~nm}$ from a HeNe laser. Raman spectra were calibrated using the $520 \mathrm{~cm}^{-1}$ silicon band. Spectral manipulations such as baseline adjustment, smoothing and normalisation were performed by using Renishaw WiRE 3.2 software. Fourier transform infrared (FT-IR) spectra were acquired from a Thermo Nicolet-Nexus spectrometer equipped with EverGlo IR source optics which provides a stabilised signal. 
Spectra were acquired in the range of $4000-500 \mathrm{~cm}^{-1}$ with $0.5 \mathrm{~cm}^{-1}$ resolution and processed using OMNIC ESP software. The solid samples were prepared for investigation by mixing with potassium bromide (KBr), then ground and pressed into disks.

\subsubsection{Electroanalytical techniques}

$\mathrm{pH}$ and $\mathrm{E}_{\mathrm{H}}$ were recorded in flotation testing and also in titrations to investigate the interaction of the flotation reagent with the sample. $\mathrm{E}_{\mathrm{H}}$ measurements during titrations were undertaken at a Pt wire (vs. a $\mathrm{Ag} / \mathrm{AgCl}$ reference electrode) and monitored using a Pine WaveNow USB potentiostat interfaced with a PC running Pine Aftermath software V1.2.4361. All $\mathrm{E}_{\mathrm{H}}$ values are reported against a $\mathrm{Ag} / \mathrm{AgCl}(3.0 \mathrm{M} \mathrm{KCl})$ reference electrode.

\subsubsection{X-ray fluorescence spectroscopy}

An X-ray fluorescence (XRF) spectrometer from Thermo Scientific (NITON XL3t) was utilised for measurement of $\mathrm{Cu}, \mathrm{Fe}$ and trace metals. The concentrate and tails samples from the flotation process were collected on filter paper, washed, dried in an oven at $60^{\circ} \mathrm{C}$ for $12 \mathrm{~h}$ then fine ground for XRF measurement using Thermo Scientific analysis software.

\subsubsection{X-ray photoelectron spectroscopy}

X-ray photoelectron spectra were collected from particulate mineral concentrate specimens embedded in freshly exposed indium foil surfaces. The samples were obtained from flotation concentrates that had been washed and dried. XPS data were obtained on an ESCALAB 250Xi spectrometer using monochromatised $\mathrm{Al} \mathrm{K}_{\alpha} \mathrm{X}$-rays focused to a spot size of $0.5 \mathrm{~mm}$ and an electron analyser pass energy of $20 \mathrm{eV}$ for narrow range scans. Included in the binding energies employed for calibration were $83.96 \mathrm{eV}$ for $\mathrm{Au} 4 f_{7 / 2}$ of metallic gold and $932.6 \mathrm{eV}$ for $\mathrm{Cu} 2 p_{3 / 2}$ of $\mathrm{Cu}$ metal. The pressure in the analysis chamber was better than 5 $\times 10^{-9}$ mbar during spectral acquisition. Acquisition of photoelectron spectra required the use of a flood gun and binding energies were referenced to $285.0 \mathrm{eV}$ for the hydrocarbon $\mathrm{C} 1 s$ photoelectrons. The possibility of beam damage by the flood gun low energy electrons was monitored and spectra were obtained as quickly 
as possible, at the expense of signal-to-noise, in order to minimise any damage arising from the secondary electrons associated with the X-ray photoemission.

\subsubsection{Scanning electron microscopy}

An FEI Quanta 200 Environmental SEM was used to characterise topography of chrysocolla and sand samples. The surface layer of a chrysocolla sample was prepared by cutting with a diamond blade on a Buehler Isomet low speed saw lubricated with water. The sample surface was ground with silicon carbide abrasive paper progressively to P1200. The ground sample was then polished with water lubricated $6 \mu \mathrm{m}$ and $3 \mu \mathrm{m}$ diamond paste laps followed by sonication for $10 \mathrm{~min}$ in de-ionised water to dislodge small particles from the surface. The ground chrysocolla, sand and concentrate samples were prepared by pressing particles into a conductive carbon paste coating on a stub holder with a thin gold coating being evaporated onto the exposed particle surfaces to prevent charging during the investigation.

\subsubsection{Atomic absorption spectroscopy}

An atomic absorption spectrometer (AAS) Varian spectrAA-10 with a $\mathrm{Cu} / \mathrm{Fe}$ cathode lamp was used to measure the $\mathrm{Cu}$ and $\mathrm{Fe}$ content of the Canadian malachite ore and concentrates. Samples were prepared by digesting the samples in aqua regia, followed by fuming to dryness, then adding excess hydrochloric acid and diluting with DDI water as required.

\subsection{Flotation experiments}

Flotation experiments were conducted using a $2.5 \mathrm{~L}$ stirred flotation cell. The flotation charge of $84 \mathrm{~g}$ or 42 $\mathrm{g}$ of chrysocolla, mixed with $\sim 1 \mathrm{~kg}$ of sand, was slurried with $1 \mathrm{~L}$ of water and transferred to the flotation cell. The slurry was stirred at $660 \mathrm{rpm}$ for $2 \mathrm{~min}$. The solids content in the cell was then adjusted to $33 \%$ by addition of approximately $1 \mathrm{~L}$ of water and stirred at $500 \mathrm{rpm}$ for $2 \mathrm{~min}$. The $\mathrm{pH}$ was adjusted to the desired value with $\sim 1 \mathrm{M} \mathrm{NaOH}$ or $\sim 1 \mathrm{M} \mathrm{HCl}$ and the collector and frother were added at the selected dosage. The $\mathrm{pH}$ was re-adjusted after the reagent addition to ensure that flotation occurred at the target $\mathrm{pH}$ during the conditioning period that was normally set at $2 \mathrm{~min}$. Flotation was commenced by introducing a compressed air flow of $7 \mathrm{~L} / \mathrm{min}$. Several concentrate collections were taken sequentially to emulate plant operation and a 
flotation time of 2 min was selected for the first concentration, followed by 3 min intervals for each of the second, third and fourth concentration steps.

\section{Results and discussion}

The surface topography of the ground chrysocolla and sand samples was investigated using SEM, prior to flotation. Images of the ground chrysocolla sample are presented in Fig. 1. The particles exhibited rough surfaces and edges with numerous surface protrusions.

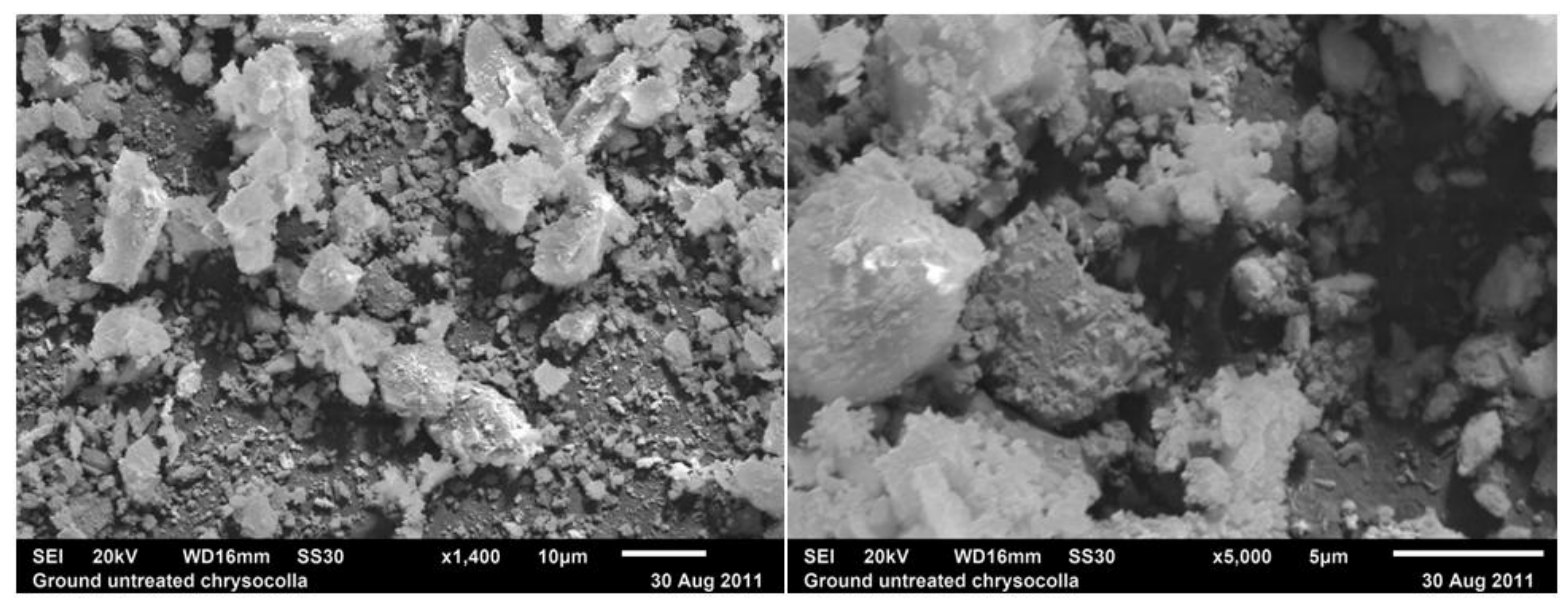

Fig. 1. Scanning electron micrographs of ground chrysocolla.

The particle roughness appeared to be independent of the particle size, with $100 \mu \mathrm{m}$ particles having similar surface roughness to the $<20 \mu \mathrm{m}$ particles. EDX analysis of a chrysocolla particle gave the following composition as \%w/w: O; 39.95, Cu; 38.23, $\mathrm{Si} ; 20.51, \mathrm{Al} ; 0.58, \mathrm{Fe} ; 0.84, \mathrm{Ca} ; 0.28 . \mathrm{EDX}$ analysis of an ironrich particle observed in the chrysocolla matrix gave a stoichiometry of $\mathrm{Fe}_{3} \mathrm{O}_{4}$. Treatment of the ground chrysocolla sample with a permanent magnet enabled collection of magnetic iron oxide particles.

In Fig. 2 the SEM images of the sand particles illustrate the sharp, compact, fractured structure that was exhibited by the ground sand. 

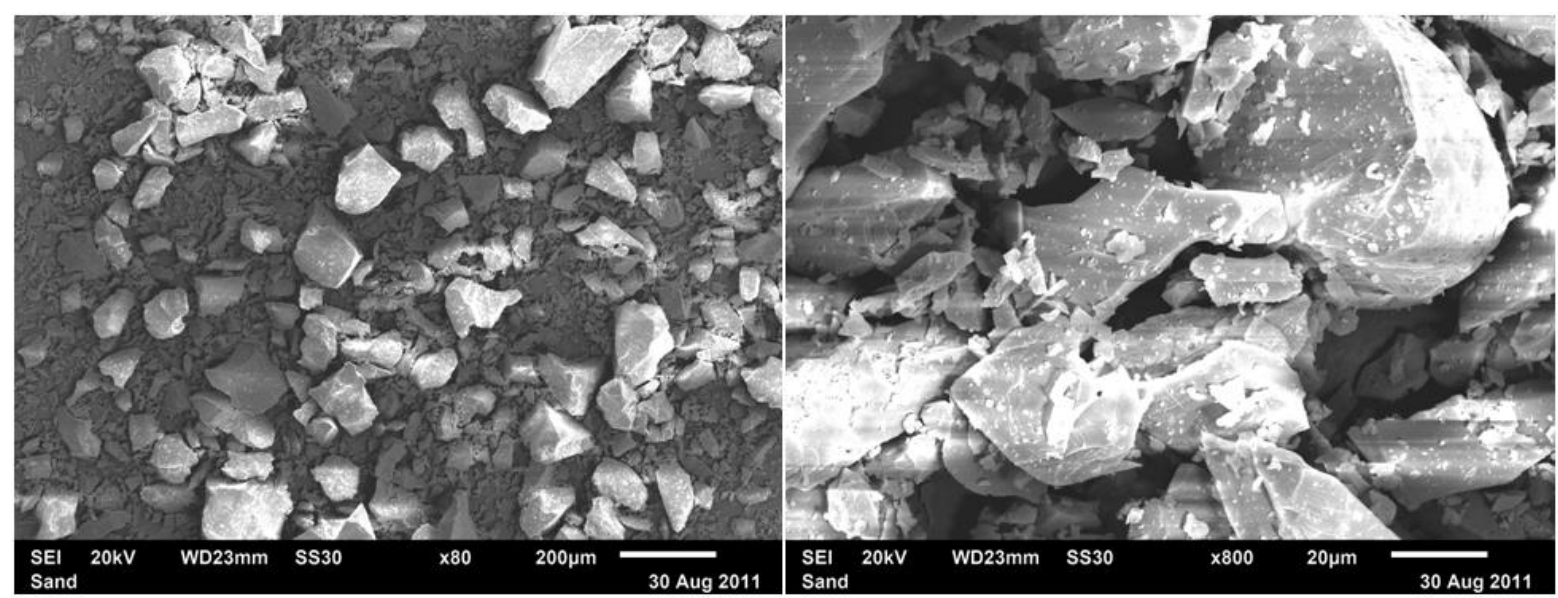

Fig. 2. Scanning electron micrographs of sand after grinding.

The sand was non-porous with liberated iron oxide particles that exhibited magnetism. The actual particle size distribution achieved by grinding was determined using the Mastersizer software and is presented in Fig. 3. The sand particle size distribution was considerably narrower than that of the chrysocolla: whereas $35 \%$ by volume of the chrysocolla particles were under $20 \mu \mathrm{m}$ in diameter only $18 \%$ by volume of the sand was in this particle size range. The volume passing $100 \mu \mathrm{m}$ was $77 \%$ for the sand and $83 \%$ for the chrysocolla.

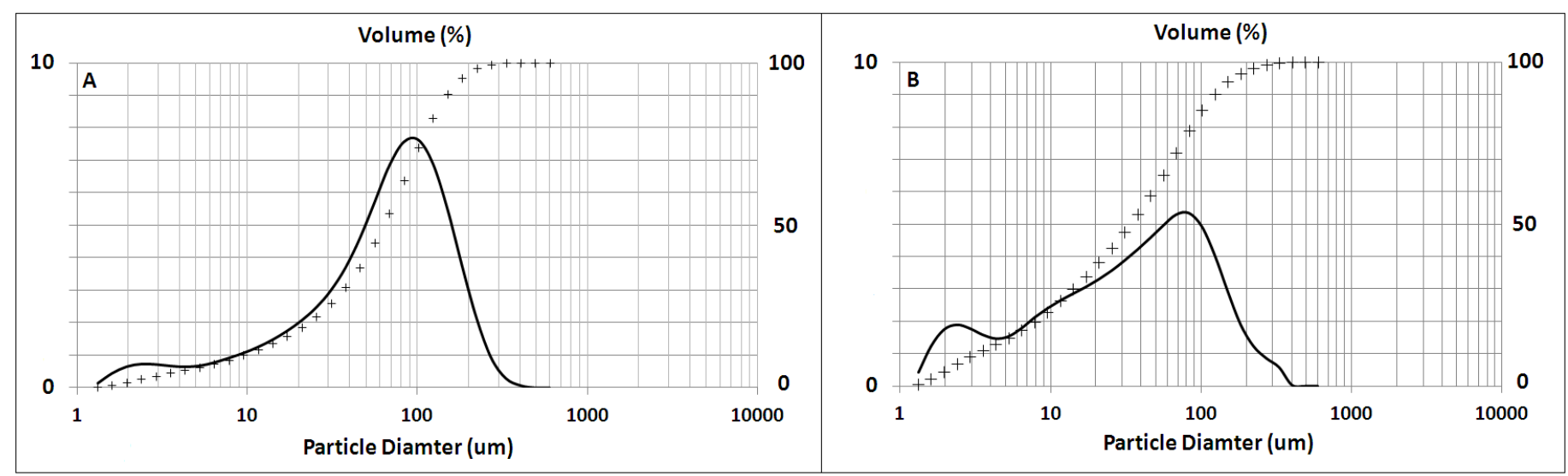

Fig. 3. Particle size analysis of sand (A) and the chrysocolla (B) samples.

XRF analyses of the chrysocolla and sand samples are presented in Table 1. It shows that the sand contained appreciable iron content. For a typical charge in the stirred flotation cell tests, containing $40 \mathrm{~g}$ of chrysocolla and $1 \mathrm{~kg}$ of sand, the nominal composition was $0.94 \% \mathrm{Cu}$ and $0.21 \% \mathrm{Fe}$, with $87 \%$ of the iron in the charge being contained in the sand fraction. The iron was present predominantly as magnetite in both chrysocolla and sand samples. 
Table 1. XRF metals analysis of Clifton chrysocolla and Gosford sand samples.

\begin{tabular}{cccc}
\hline Chrysocolla (metal ww\%) & \multicolumn{2}{c}{ Sand (ww\%) } \\
\hline $\mathrm{Cu}$ & 24.37 & $\mathrm{Fe}$ & 0.18 \\
$\mathrm{Fe}$ & 0.77 & $\mathrm{Cr}$ & 0.05 \\
$\mathrm{Zn}$ & 0.08 & $\mathrm{Ni}$ & 0.02 \\
$\mathrm{Mo}$ & 0.06 & $\mathrm{Cu}$ & 0.01 \\
$\mathrm{~Pb}$ & 0.03 & & \\
$\mathrm{Bi}$ & 0.01 & & \\
$\mathrm{Nb}$ & 0.01 & & \\
\hline
\end{tabular}

\subsection{Batch flotation tests}

A series of batch tests were undertaken on a $\mathrm{kg}$ scale in the $2.5 \mathrm{~L}$ stirred flotation cell. An initial run investigated the flotation of a $1.9 \% \mathrm{Cu}$ sand-chrysocolla mixture prepared by mixing $85.29 \mathrm{~g}$ of the dryground chrysocolla with $993 \mathrm{~g}$ of ground sand. The target $\mathrm{pH}$ for the test was 10, and the flotation collector was added in four steps to emulate a four-stage flotation process with sequential collector dosage to the flotation cell train. The AM2 dose level was determined by the observed flotation response without consideration of the reagent consumption level. In Fig. 4 we present the flotation test data sheet recorded for this test with a total AM2 dose of $1.2 \mathrm{~kg} / \mathrm{t}$ (tonne of ore) (equivalent to $700 \mathrm{~g} / \mathrm{t}$ for each $1 \%$ of contained copper).

In the four-stage flotation test, $97.5 \%$ of the total copper was recovered by AM2, with MIBC frother used for the first two stages and IF50 added as the frother in the final two stages. $54.2 \%$ of the total iron was also collected $(1.4 \mathrm{~g})$, the majority of this coming from the sand fraction. Assay of the copper gave the highest proportion of acid soluble copper in the first concentrate sample (97.4\%), a proportion which decreased with the extent of collection, the final concentrate sample having $92.1 \%$ acid soluble copper. These results indicated that the fastest floating copper minerals contain the highest acid soluble copper content. The overall AM2 consumption in this test was $1.2 \mathrm{~kg} / \mathrm{t}$ of ore. In a commercial plant environment, it is unlikely that the fourth stage would be employed to recover only $5 \%$ of the acid soluble copper. 


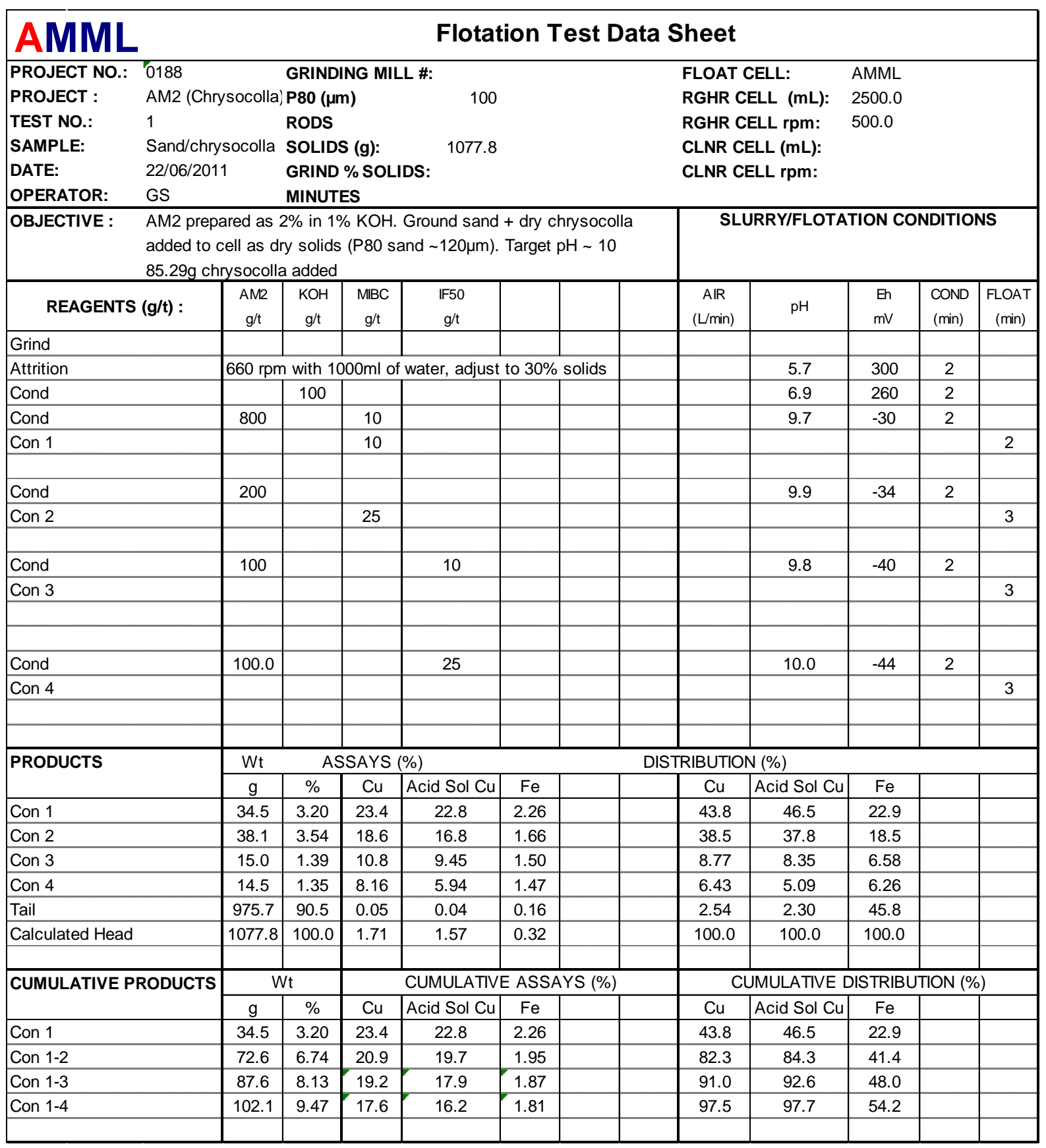

Fig. 4. Flotation test data result sheet for the chrysocolla-sand test with sequential AM2 addition.

The recoveries of iron and copper from the sand-chrysocolla charge at each stage of flotation are presented in Fig. 5. The chrysocolla was recovered efficiently and $82.3 \%$ of the mineral had been collected with the second addition. The iron (mainly from the sand) was also collected, with $41.4 \%$ recovered at the same stage. 


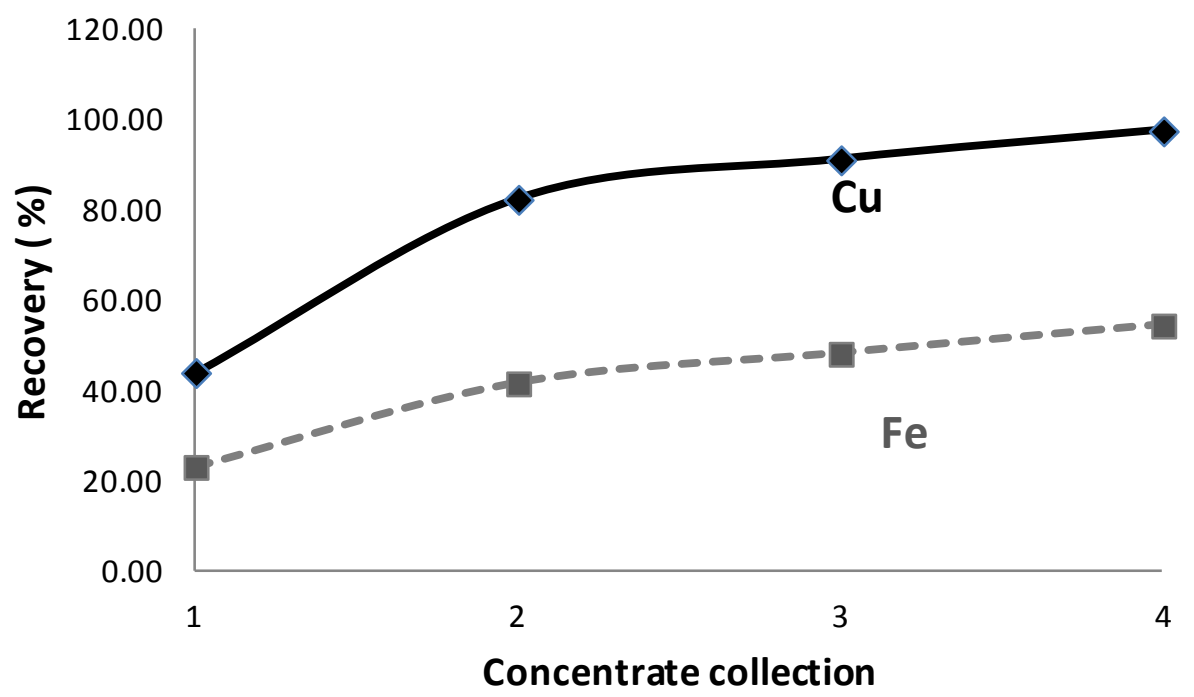

Fig. 5. Percentage recovery of total copper and iron for the 4 stage AM2 flotation test.

The sand-chrysocolla charge is a combination which was chosen to minimise the collector interaction with gangue materials and for demonstration of the chrysocolla collection effectiveness. The grade of the concentrate achieved in this case was indicative of silica entrainment in the flotation process. The copper grade versus recovery of the charge from each flotation step is presented in Fig. 6. The maximum grade achievable would be the mass \% of copper in the ground Clifton chrysocolla sample, $24.3 \%$ (provided no significant impurity phase is present). It is apparent that the first concentrate sample collected was almost pure chrysocolla, with sand being an increasing proportion of the collected material as the process lowered the chrysocolla content of the flotation cell charge.

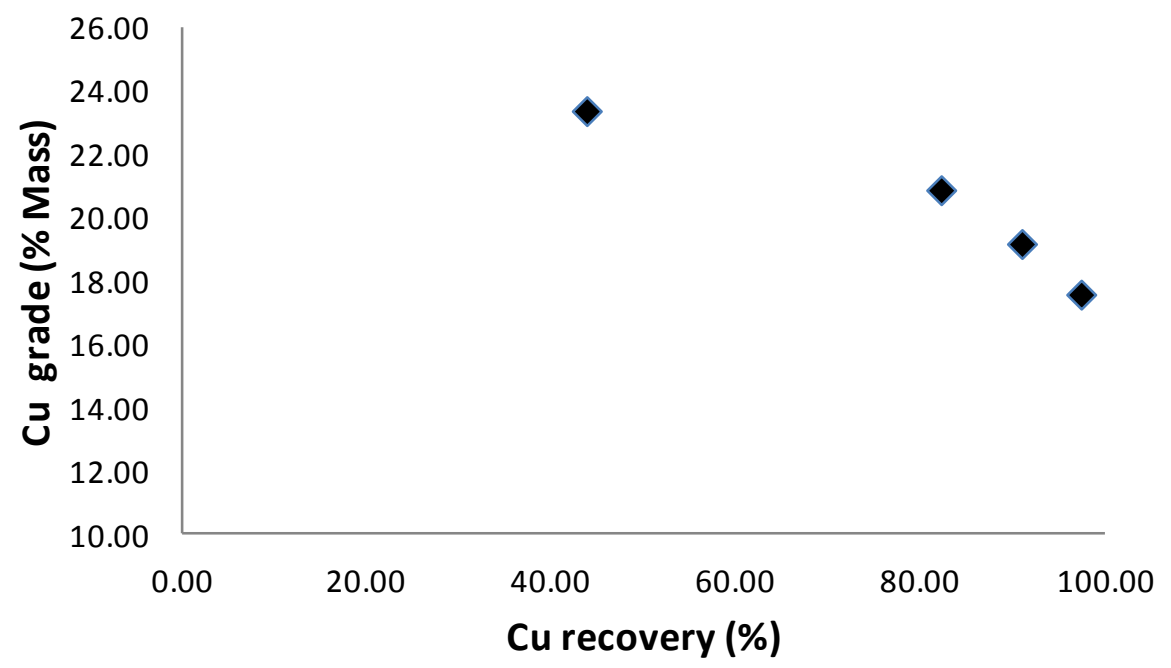

Fig. 6. Variation in copper grade with recovery for the 4 stage AM2 flotation test. 
There have been a number of reports of the $\mathrm{pH}$ dependence of flotation concerned with n-octanohydroxamate and oxide copper ores. These have employed contact angle measurements (HerreraUrbina et al., 2010), Hallimond flotation cells (Fuerstenau and Pradip, 1984) and Denver cells (Lee et al., 1998; Lee et al., 2009).

Experiments were undertaken to assess the recovered copper grade dependence on the $\mathrm{pH}$ used for the flotation of the chrysocolla. The test conditions for these measurements utilised similar conditioning and collection times to the experiments presented in Fig. 4 but with a lower initial chrysocolla content and scaled collector addition levels. A four-step sequential addition of AM2 as a $2 \%$ solution in $1 \% \mathrm{KOH}$ was employed: $400 \mathrm{~g} / \mathrm{t}$ with $20 \mathrm{~g} / \mathrm{t}$ IF50 for the first step, followed by $100 \mathrm{~g} / \mathrm{t}$ AM2 + $20 \mathrm{~g} / \mathrm{t} \mathrm{IF50,} \mathrm{then} 2$ further collections at $50 \mathrm{~g} / \mathrm{t}$ AM2 $+20 \mathrm{~g} / \mathrm{t}$ IF50. The grades obtained in this series of flotation experiments as a function of the $\mathrm{pH}$ of the first flotation step, for chrysocolla-sand charges initially containing $0.85 \% \mathrm{Cu}$ are presented in Fig. 7. The data is indicative of poorer flotation performance observed for hydroxamate at a $\mathrm{pH}$ below 9.5 under the conditions used for these experiments. The recovery is presented as the contained copper content of the blended sand-chrysocolla charge.

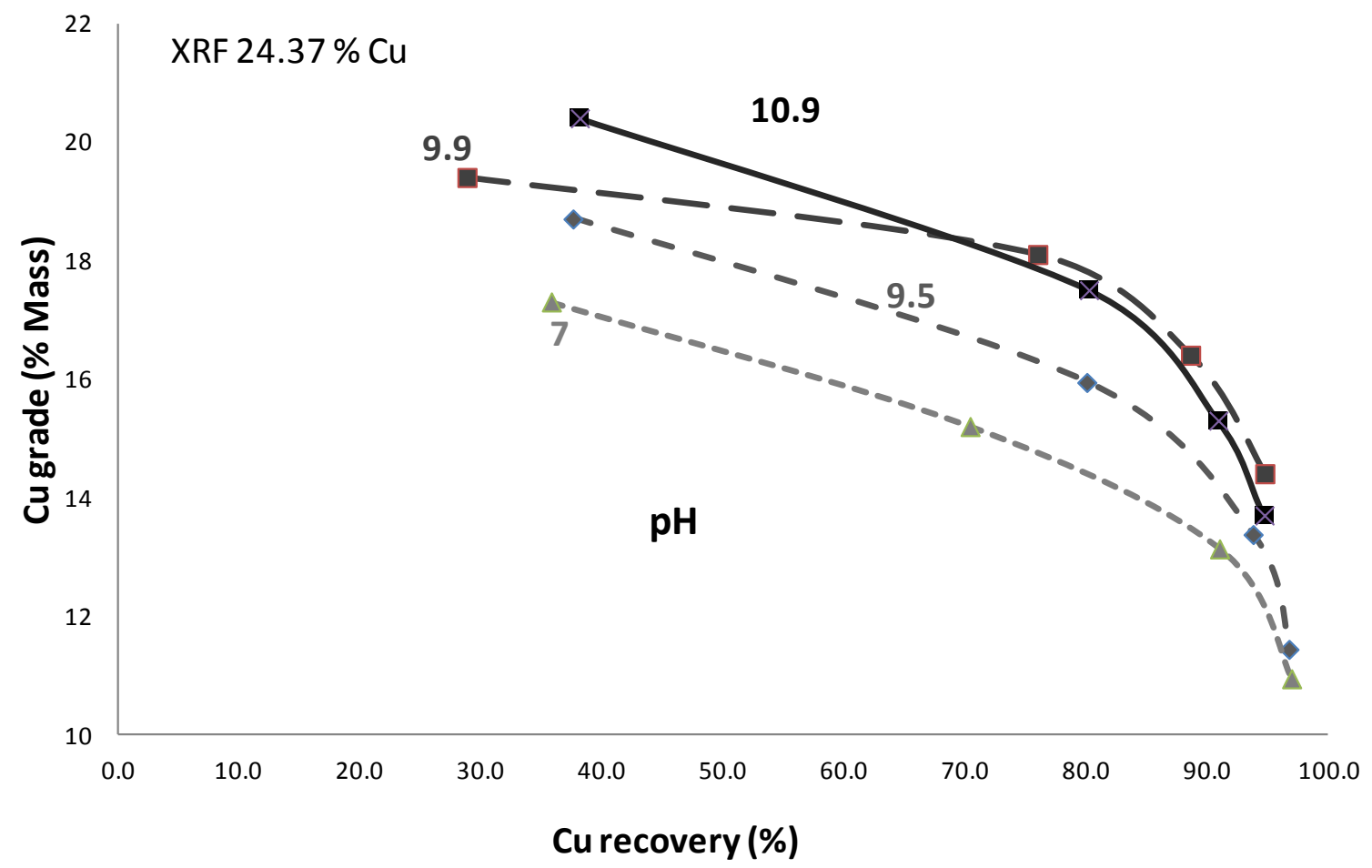

Fig. 7. $\mathrm{pH}$ dependence of $\mathrm{Cu}$ grade as a function of $\mathrm{Cu}$ recovery for sequential AM2 addition at $600 \mathrm{~g} / \mathrm{t}$. 
The grade response exhibited by the data presented in Fig. 7 is of noticeably lower copper content than that observed for the $1.2 \mathrm{~kg} / \mathrm{t}$ data obtained from a $1.71 \%$ copper head grade. While the data indicate that (predominantly) more sand is collected under the lower AM2/copper content conditions, this can be attributed (in part) to the fact that at a starting grade of $0.85 \% \mathrm{Cu}$, the grade recovery curves presented in Fig. 7 cover only the lower half of the sand-chrysocolla copper content range than is covered by the data presented in Fig. 6.

Iron recovery exhibited greater $\mathrm{pH}$ dependence than that observed for copper in sequential AM2 addition experiments. In Figs. 8 and 9, column charts are presented that illustrate the distribution of the collected metals over the four collection steps for the four $\mathrm{pH}$ conditions. The relative contributions of the collection steps are apparent, and it can be seen that the contained iron floats to a greater extent than the copper in the latter flotation steps. The columns represent the cumulative \% recovery of $\mathrm{Cu} / \mathrm{Fe}$ at each collection.

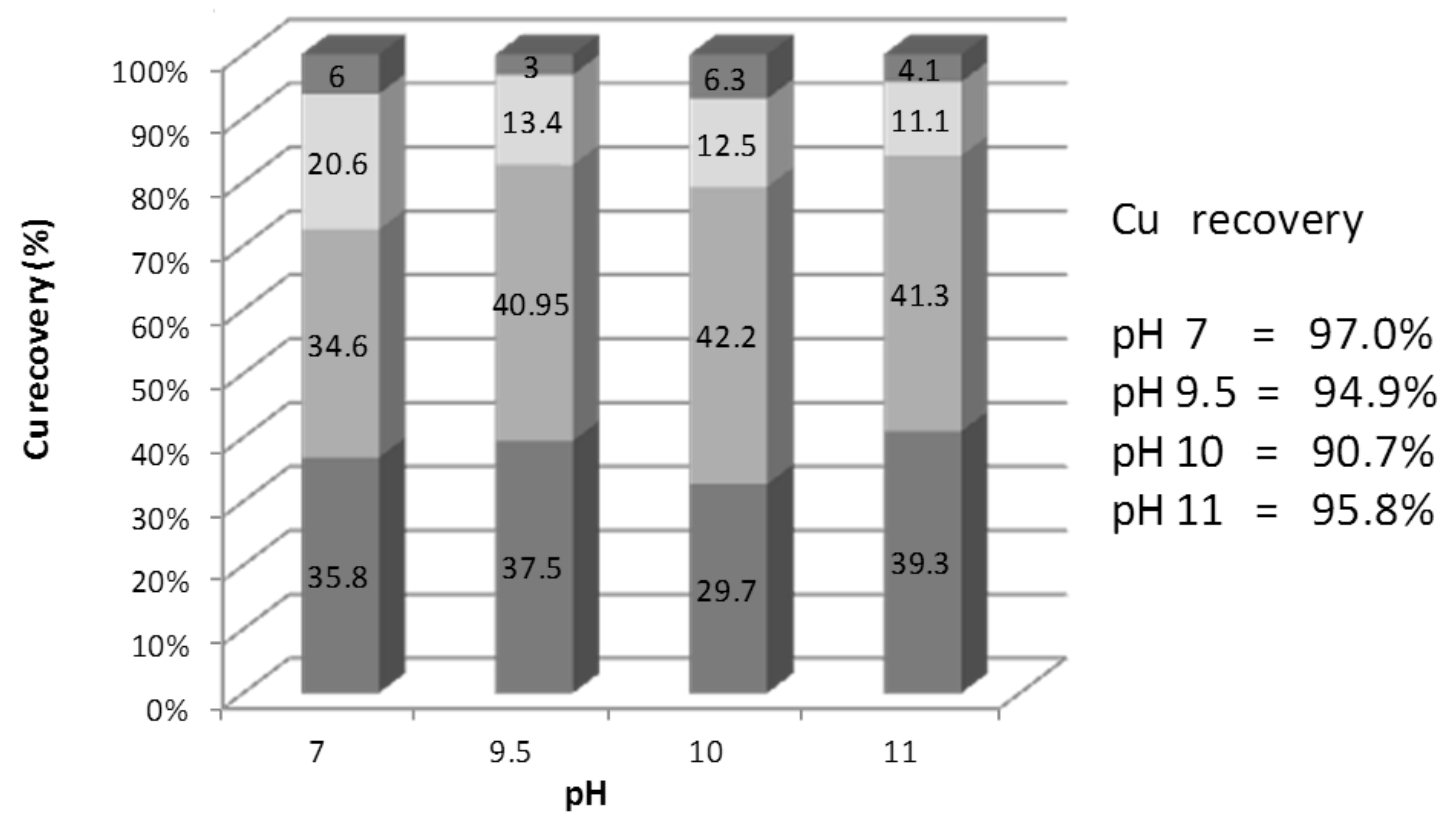

Fig. 8. Copper recovery at selected flotation $\mathrm{pH}$ showing the 4 concentrate collections.

At all $\mathrm{pH}$ values tested, the majority of the chrysocolla was collected in the first two flotation steps. 


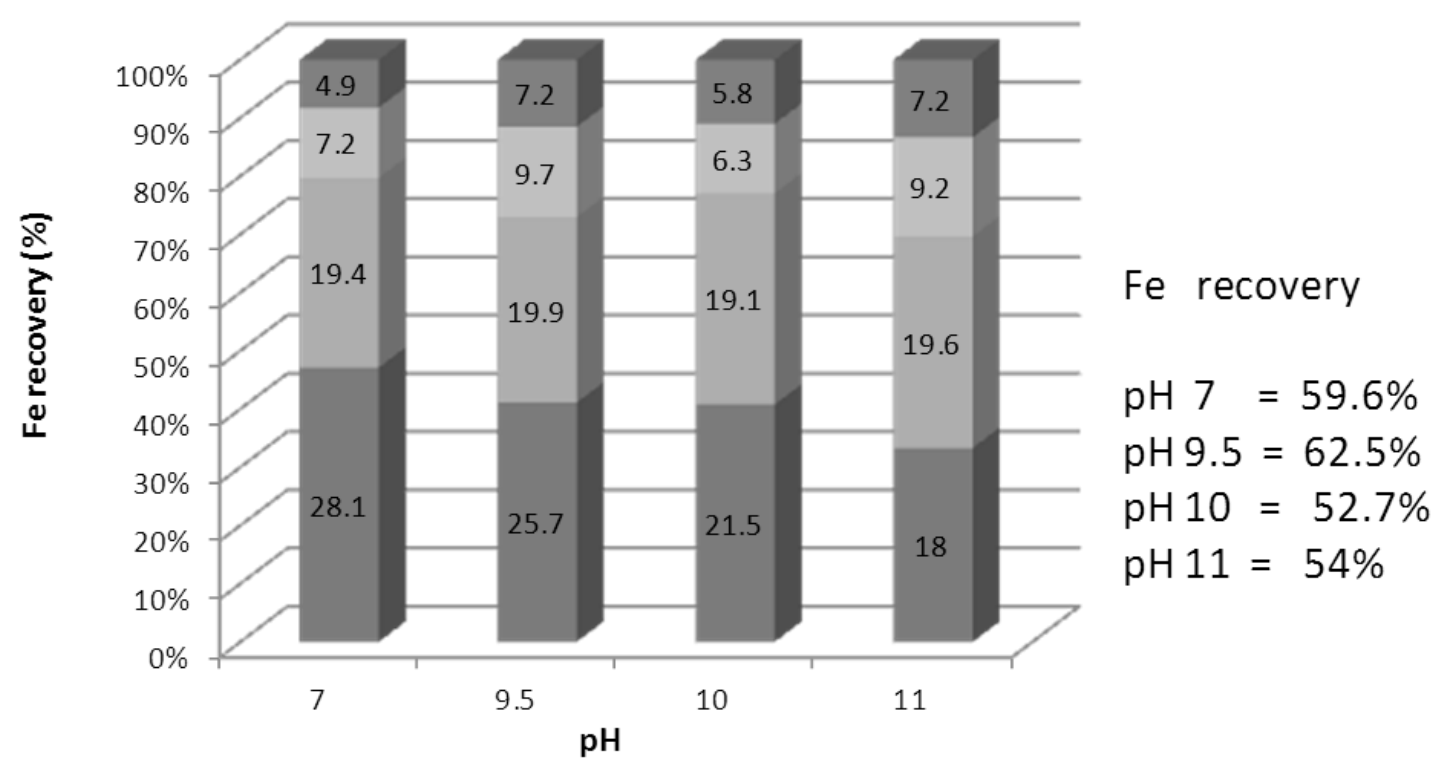

Fig. 9. Iron recovery at selected flotation $\mathrm{pH}$ showing the 4 concentrate collections.

Less than two thirds of total iron was recovered from the sand-chrysocolla charge, and the recovery was most efficient at lower $\mathrm{pH}$ and was spread evenly across the 4 collections compared to the measured copper recovery.

The sequential addition of flotation reagent in bench-scale testing was an attempt to emulate the role of flotation banks in the plant. In many plants designed for oxide ore flotation, it is not convenient to have multiple collector dosing points. This impacts on the flotation process, where grade and recovery can be affected by time. The grade-recovery data for sequential AM2+IF50 addition, single dose AM2+sequential IF50 addition and for single dose AM2, stirred for 30 min prior to flotation+sequential IF50 addition are presented in Fig. 10. 


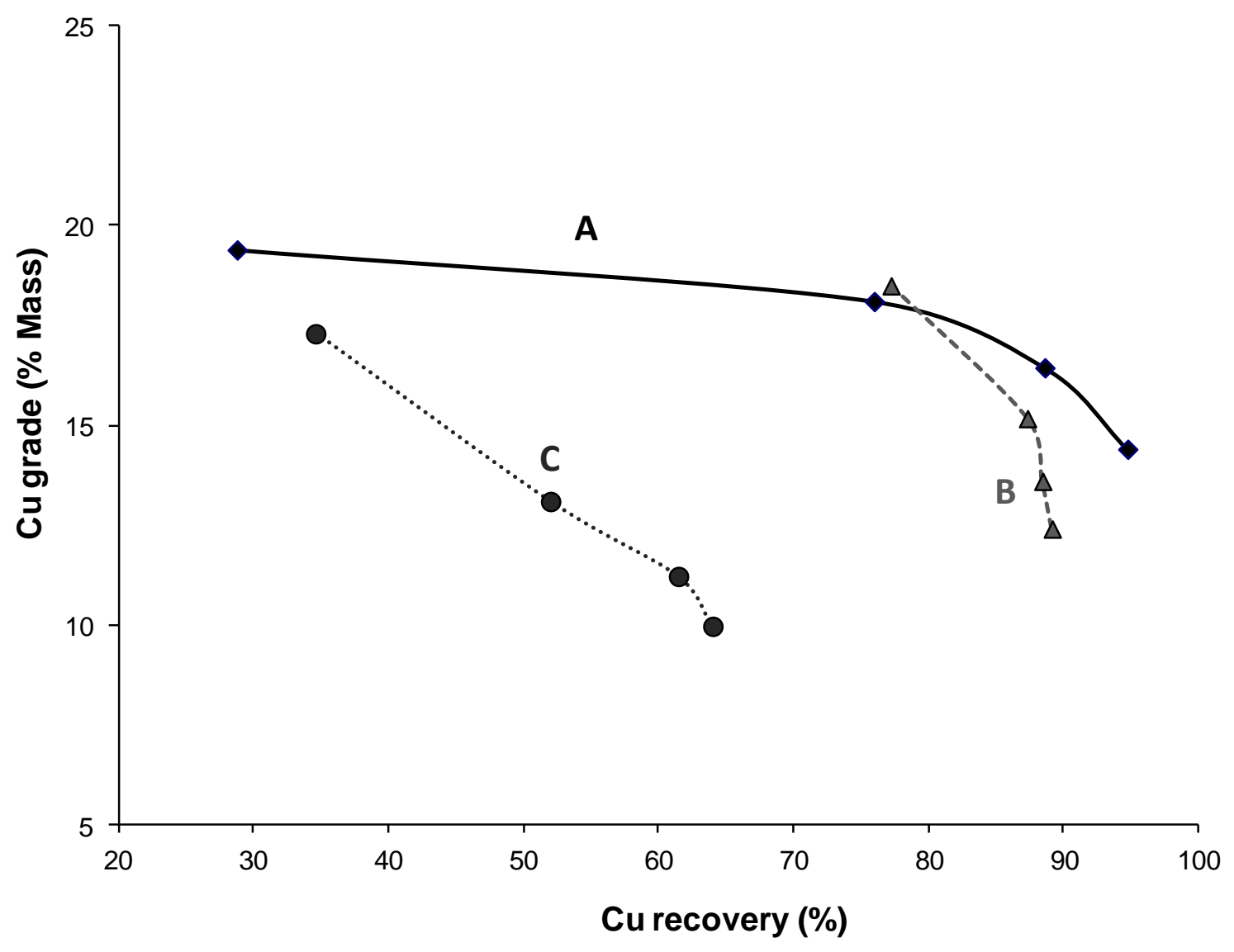

Fig. 10. Curve $\mathrm{A}$ is sequential AM2 addition, $\mathrm{B}$ is for a single dose at the start of the flotation experiment and $\mathrm{C}$ is dosed with AM2 and stirred for 30 minutes prior to commencement, $\mathrm{pH} 10$.

The AM2 single dose addition was undertaken to investigate whether the flotation response observed for the sequential addition was sufficient to utilise a single-point collector addition. The recovery rate of copper for the AM2 single dose addition is compared to that of a similar total dose AM2 4 stage addition in this figure. The collection protocol for the single dose experiment was the same as for the 4 stage addition, except that all the AM2 was added in the initial float, with the subsequent flotation steps only adding IF50. The initial collection yielded $77.2 \%$ of the copper at a grade of $18.5 \%$. The total recovery result for AM2 single dose addition indicated $91.3 \%$ of copper was recovered and a $55.5 \%$ iron recovery, values that were slightly lower than the recovery rate of the AM2 stage addition of $95.3 \%$ and $52.7 \%$ for copper and iron respectively. Fig. 10 also presents data on the loss of AM2 with residence time in the flotation pulp. In Fig. 10, curve $\mathrm{C}$, an extended conditioning time prior to chrysocolla flotation, of $30 \mathrm{~min}$ for the single dose regime of AM2, and the same collection protocol clearly demonstrated that the flotation performance for the AM2 was substantially reduced when the time between collector addition and concentrate collection was 
extended. The copper recovery was reduced to $70.8 \%$ from $95.3 \%$ obtained for the 2 min single AM2 dose system, and iron recovery fell from $55.5 \%$ to $47.6 \%$. Herrera-Urbina et al. (2010) have observed lower copper recovery when conditioning time was extended during Hallimond tube experiments, at $\mathrm{pH}$ values lower than those used here. They attributed their low recovery to significant dissolution of copper from their chrysocolla. Dissolution of copper would lead to formation of copper hydroxamate and removal of the collector from solution. Any large, free hydrophobic copper hydroxamate particles dislodged from the chrysocolla surface by sand abrasion would report to the concentrate but small copper hydroxamate particles may not be collected. A lower grade also may be attributable to collection of copper hydroxamate coated, or iron hydroxamate coated, silica. Copper could be lost from the system through silica particles that were only partially covered by abraded copper hydroxamate, with the larger particles not being sufficiently hydrophobic to be floated, such that these report to the tailings and, consequently, the metal recovery decreases.

The dependence of the flotation process on the nature of the copper mineral was investigated by utilising chrysocolla with malachite-azurite components to prepare a sand-chrysocolla-malachite-azurite charge with a combined copper content of $1 \%$ by mass. The grade $v s$. recovery measured from this sample could then be directly compared to the sand-chrysocolla samples. In Fig. 11 we present the recovery grade curves obtained from the mixed silicate-carbonate sample and a chrysocolla-sand sample of the same copper head grade treated under the sequential addition flotation conditions observed at $\mathrm{pH} 10$. 


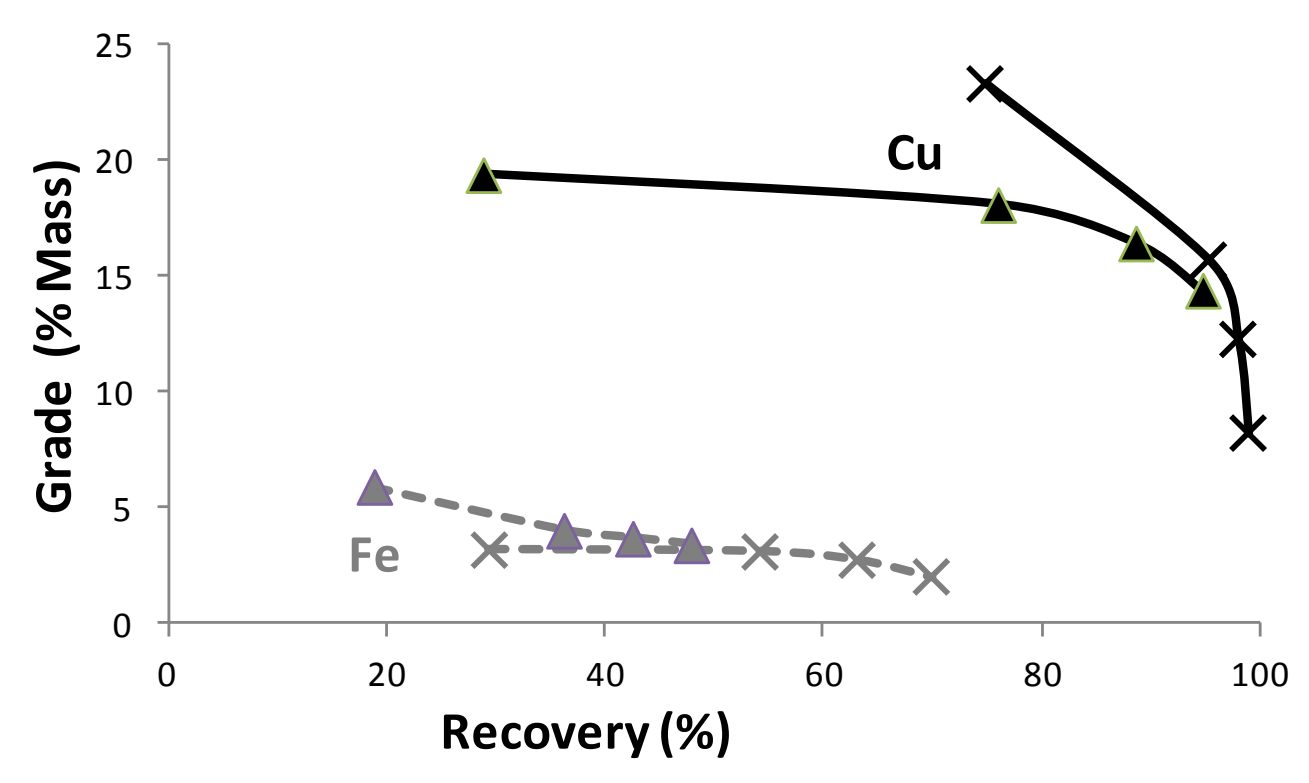

Fig. 11. Grade vs. recovery for chrysocolla $(\boldsymbol{\Delta})$ and chrysocolla + malachite/azurite $(\mathbf{X})$ samples, pH 10.

The sample comprised of a mixture of chrysocolla and malachite/azurite exhibited a faster, higher-grade copper flotation and a lower-grade recovery for the iron than that of the sand-chrysocolla mixture. The grade for the chrysocolla is $36 \% \mathrm{Cu}$, and, for our sample, the maximum grade from XRF analysis was $24.37 \%$. Assuming 56\% as a maximum grade for the copper carbonates, we would have a grade near $56 \%$ if only carbonate material floated initially, or, $24 \%$ if only the silicate floated. It is apparent the copper minerals are being floated simultaneously, and it is possible that the faster (and higher) recovery rate is determined by the greater theoretical grade in the composite copper sample tested.

Ammonia solution was tested for $\mathrm{pH}$ adjustment, and at the concentration required for maintaining a $\mathrm{pH}$ of 9.5 was found to have no measurable effect on the grade or recovery for the copper or the iron contained in the chrysocolla charge.

\subsection{XPS studies of concentrate samples}

Two samples of the first-step concentrate from sequential addition experiments were investigated. These were from a $0.8 \% \mathrm{Cu}$ content sand-chrysocolla charge floated at $\mathrm{pH} 6.5$ (mass recovery data first section of column labelled 7 in Fig. 10 and Fig. 11), and from the chrysocolla-malachite-azurite-sand charge floated at pH 10 (grade vs recovery data presented in Fig. 10). 
The concentrate was dried on a paper filter using heat lamps, then transferred to a glass dish and held in an oven at $60^{\circ} \mathrm{C}$ for $12 \mathrm{~h}$. The sample for XPS study was taken after the mass of dried concentrate had been determined. The concentrate samples were transported in zip-lock plastic bags. Especially because of the absence of special handling of the concentrate samples, it might be expected that the residual collector concentration on the particles would be lower than while the particles were in the flotation froth.

The samples were sub-sampled for XPS characterisation and a small quantity mounted on double-sided adhesive tape with only very gentle pressure applied to the particles to assist their adhesion, but to minimise further damage to any adsorbate on the surface of the particles. Spectra were obtained from a single $500 \mu \mathrm{m}$ area of each specimen. Because of the poor electrical conductivity of the oxide $\mathrm{Cu}$ minerals, the use of an electron flood-gun was necessary for XPS analysis with monochromatic X-rays to compensate for specimen charging as a result of photoemission. The low energy electrons $(175 \mu \mathrm{A}, \sim 4 \mathrm{eV})$ from the flood-gun can potentially stimulate desorption and reduction of $\mathrm{Cu}^{\mathrm{II}}$ to $\mathrm{Cu}^{\mathrm{I}}$, therefore $\mathrm{N} 1 s$ and $\mathrm{Cu} 2 p$ spectra were determined as soon as possible after the flood gun had stabilised, and a second $\mathrm{N} 1 s$ spectrum was determined at the end of the spectral suite to assess the extent of any beam damage. All spectra were obtained as rapidly as possible, at the expense of signal-to-noise, to minimise beam damage.

In minimising peak broadening from a non-uniform potential within the specimen surface layer, the low energy electrons 'over-compensate' for charging and the measured photoelectron binding energies are typically $4 \mathrm{eV}$ lower than their correct values. The measured binding energies are corrected by assuming that they will all be affected by the same energy, and adjusting them so that the hydrocarbon $\mathrm{C} 1 \mathrm{~s}$ binding energy is $285.0 \mathrm{eV}$. For chrysocolla, the $\mathrm{Cu} 2 p_{3 / 2}$ and $\mathrm{Si} 2 p_{3 / 2}$ binding energies are available as a check on the validity of the correction procedure.

\subsubsection{Sample collected at $\mathrm{pH} 6.5,400 \mathrm{~g} / \mathrm{t} A M 2$ and $20 \mathrm{~g} / \mathrm{t}$ IF50}

Surprisingly, the surface $\mathrm{C}$ concentration ( 15 at $\%$ ) was relatively low, suggesting not only that extraneous post-collection contamination of the concentrate might not have been a serious problem, but also that residual adsorbed hydroxamate might also be low. However, the surface $\mathrm{Cu}$ concentration was only $\sim 5.5$ at $\%$ whereas that of $\mathrm{Si}$ was $\sim 22$ at $\%$, raising the possibility that sampling and/or sub-sampling might not 
have been representative. About 1 at $\% \mathrm{Fe}$ was also present, but the Ca concentration $(\sim 0.2$ at $\%)$ and $\mathrm{Al}$ concentration $(\sim 1.7$ at\%) were consistent with the $\mathrm{Cu}$ concentration. The XRF analysis of the ground chrysocolla sample (Table 1) gave a $\mathrm{Cu}$ concentration of $24.4 \mathrm{wt} \%$, whereas a model chrysocolla sample would be expected to be close to $36 \% \mathrm{Cu}$ by weight, or near 6.7 at $\%$ including all atoms ( $\mathrm{H}$ inclusive). Relative to the $\mathrm{Cu}$ content, the surface $\mathrm{N}$ concentration ( $\sim 0.7$ at $\%)$ was unexpectedly high.

The N $1 s$ spectrum, determined at the outset, comprised a major component at $400.0 \mathrm{eV}$ accounting for $80 \%$ of the intensity, with the remaining $20 \%$ near $402 \mathrm{eV}$. In the spectrum determined at the end, the $400.0 \mathrm{eV}$ component accounted for $85 \%$ of the intensity, with the other $15 \%$ at $\sim 401.7 \mathrm{eV}$. Minor ( 7\%) desorption of $\mathrm{N}$ in the intervening period was evident, and essentially all of that loss was $\mathrm{N}$ with the higher $1 s$ binding energy, implying that this component was more likely to have arisen from protonated hydroxamate $\mathrm{N}$ in coadsorbed hydroxamic acid than from metal hydroxamate. The retention of some co-adsorbed hydroxamic acid would not be unreasonable given the relatively low $\mathrm{pH}$ of flotation test $\mathrm{T} 9$ (target $\mathrm{pH}$ 7). The principal $\mathrm{N} 1 s$ component at $400.0 \mathrm{eV}$ is consistent with the presence of $\mathrm{Cu}$ hydroxamate.

Potassium was quite evident $(0.25$ at $\%)$ at the surface of the particles, and it is possible that the source of at least some of that $\mathrm{K}$ could have been the $\mathrm{KH}$ (hydroxamate) ${ }_{2}$ collector. It should be noted that when singlepiece mineral specimens are rinsed with water following conditioning in potassium hydroxamate solution, residual $\mathrm{K}$ is usually not present.

Approximately $7 \%$ of the $\mathrm{C} 1 \mathrm{~s}$ intensity (equivalent to $\sim 1$ at $\%$ at the surface) would have arisen from carbonate, most probably from malachite in the predominantly chrysocolla ore. The $\mathrm{Cu} 2 p$ spectrum was largely characteristic of that observed for chrysocolla, including the obvious, but unresolved component near 933.4 $\mathrm{eV}$. That low binding energy component can be assigned to $\mathrm{Cu}^{\mathrm{I}}$ that has been reduced from $\mathrm{Cu}^{\mathrm{II}}$ by secondary electrons, in association with water loss from the chrysocolla structure to the UHV of the spectrometer, rather than $\mathrm{Cu}^{\mathrm{I}}$ oxide in the unaltered chrysocolla (Parker et al., 2012). However, the $\mathrm{Cu} 2 p$ final state satellite structure was consistent with the presence of $\mathrm{Cu}$ hydroxamate at the surface of the chrysocolla and/or the presence of some malachite in the concentrate. 
The elemental composition estimated by XPS of this stage 1 concentrate was comparable with that for the sand-chrysocolla sample. Minor differences included slightly lower concentrations for $\mathrm{Cu}, \mathrm{Al}$ and $\mathrm{Fe}$, and slightly higher values for $\mathrm{Ca}$ and $\mathrm{K}$. For this concentrate, the $\mathrm{N} 1 s$ spectrum consisted essentially of one component at $400.0 \mathrm{eV}$. The absence of any co-adsorbed hydroxamic acid can be rationalised because the flotation had been carried out at $\mathrm{pH} 10$. The $\mathrm{Cu} 2 p$ spectrum was largely similar to that for chrysocolla, including the $\mathrm{Cu}^{\mathrm{I}}$ component near $933.4 \mathrm{eV}$, with a superimposed contribution from $\mathrm{Cu}$ hydroxamate and/or malachite and azurite. The carbonate peak in the $\mathrm{C} 1 s$ spectrum was more intense, as expected given the presence of the basic $\mathrm{Cu}$ carbonates in the ore floated.

\subsection{Sulfidising conditions}

A combination of $\mathrm{NaSH}$ and AM2 was also tested in the stirred flotation cell in order to investigate the flotation response of chrysocolla in the presence of sulfidising chemicals together with AM2. A single dose of $200 \mathrm{~g} / \mathrm{t}$ of $\mathrm{NaSH}$ was added to the flotation cell before adding the first dose of AM2 in a four stage sequential flotation test.

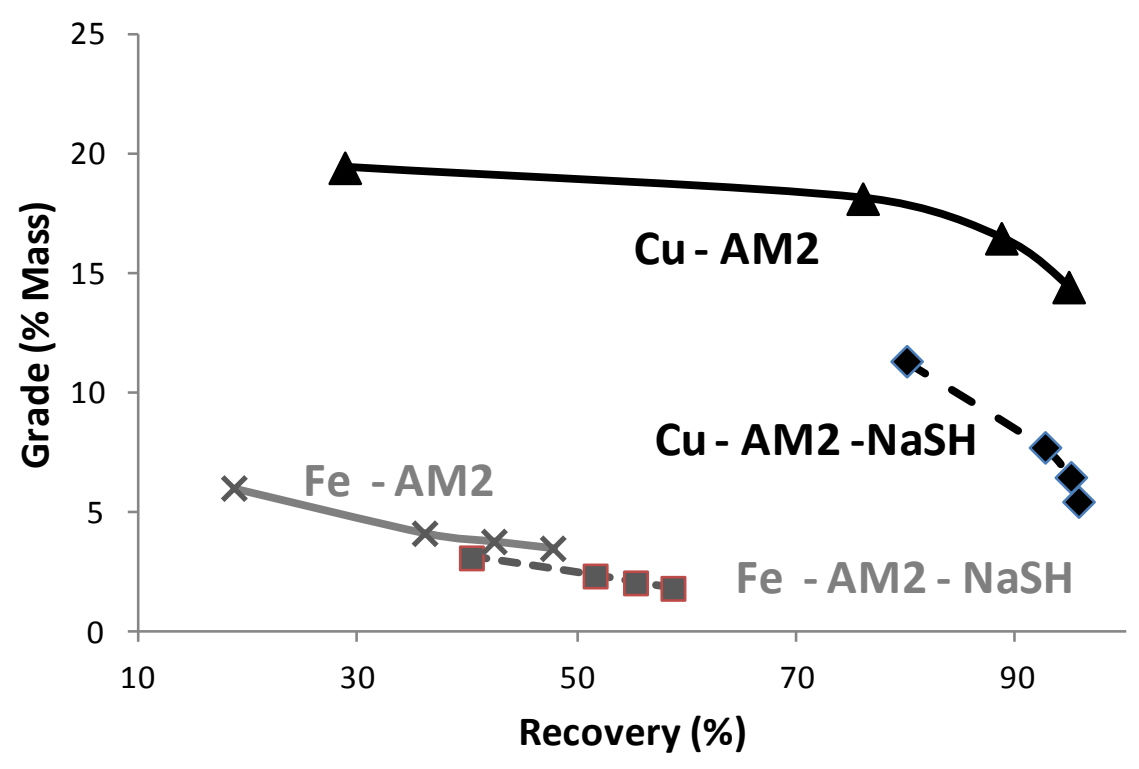

Fig. 12. Effect of added $\mathrm{NaSH}$ on the grade and recovery of chrysocolla concentrate, pH 10, with sequential addition of AM2. 
The combination of $\mathrm{NaSH}$ and AM2 addition produced a $96.6 \%$ copper recovery and $62.1 \%$ iron recovery compared to the AM2 only addition yield of $95.3 \% \mathrm{Cu}$ and $52.7 \% \mathrm{Fe}$ (Fig. 12). The major effect of added $\mathrm{NaSH}$ was a substantial decrease in the concentrate grade (for both $\mathrm{Cu}$ and $\mathrm{Fe}$ ) and a significant increase in the total iron recovery of the collected concentrate.

\section{4. $p H-E_{H}$ measurements}

The stirred bench-scale flotation cell was monitored for $\mathrm{pH}$ and the potential measured at a platinum electrode ( $\mathrm{Pt}$ vs. saturated calomel electrode, commonly but incorrectly referred to as $\mathrm{E}_{\mathrm{H}}$ ) during experiments undertaken collecting the chrysocolla concentrate. The Pt electrode potential was observed to exhibit a non-linear change near $\mathrm{pH} 9$ in these experiments. The sand-chrysocolla (-magnetite) system being investigated was not expected to deviate from a linear potential $\mathrm{pH}$ dependence $(59.1 \mathrm{mV} / \mathrm{pH}$ unit $)$ determined by the reduction of oxygen on the Pt surface of the monitoring electrode.

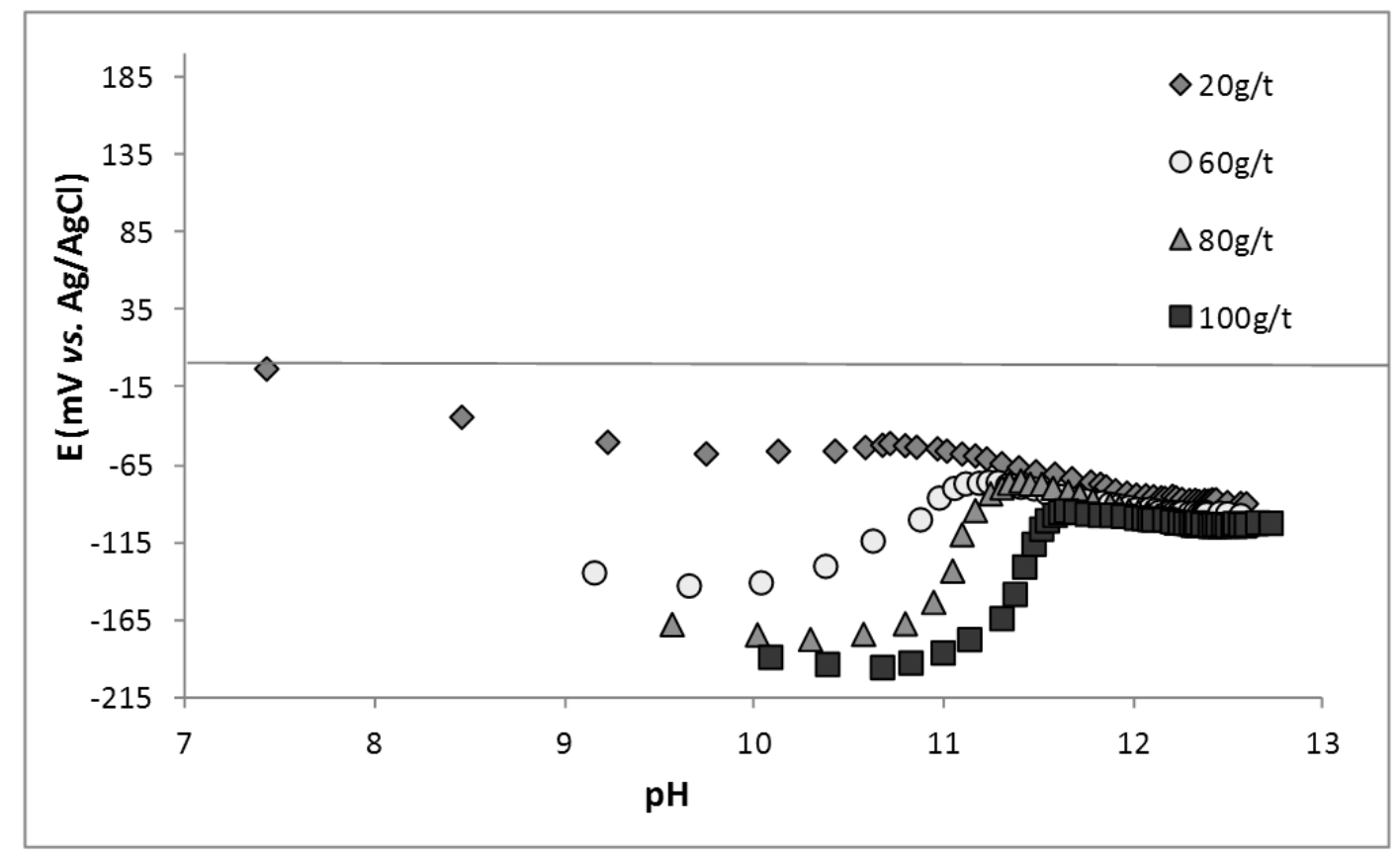

Fig. 13. Pt rest potential vs. $\mathrm{pH}$ at various levels of AM2 in chrysocolla sand slurry titrated with $0.178 \mathrm{M} \mathrm{KOH}$.

The nature of this deviation was investigated through monitoring Pt electrode potential changes during titration of sand-chrysocolla hydroxamate slurry with $\mathrm{KOH}$. The non-linear potential $\mathrm{pH}$ dependence was observed to be dependent on the dose rate of AM2. In Fig. 13 the Pt electrode potential variation with $\mathrm{pH}$ observed for varying doses of AM2 to a $30 \% \mathrm{w} / \mathrm{w}$ slurry of $0.8 \%$ copper as chrysocolla in sand is presented. 
It is possible that we are observing an interaction between iron and the n-octanohydroxamate at the $\mathrm{Pt}$ electrode, and that this is responsible for observed $\mathrm{pH}$ dependence deviation of the rest potential of the $\mathrm{Pt}$ electrode from the Nernstian slope expected for the $\mathrm{O}_{2} / \mathrm{H}_{2} \mathrm{O}$ couple $(59.1 \mathrm{mV})$.

\subsection{Vibrational spectroscopy}

Raman and FT-IR spectroscopy can be used to identify the hydroxamate species present in or on the chrysocolla particles, provided the quantity present is sufficient. In Fig. 14 the Raman and FT-IR spectra of a ground chrysocolla sample are presented.

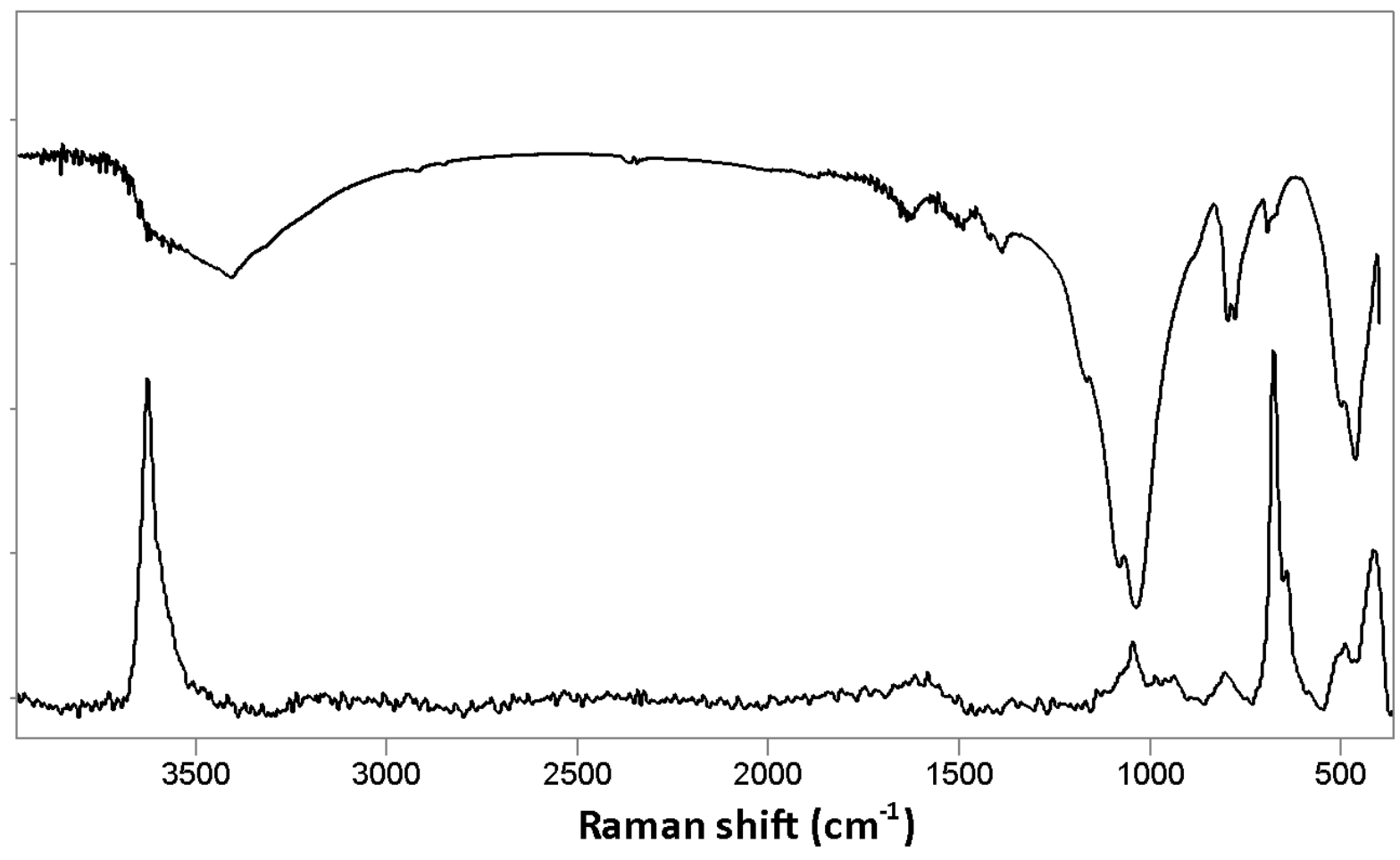

Fig. 14. Spectra from ground chrysocolla (Raman) and in KBr (FT-IR) (top).

The spectral features observed are described in Parker et al. (2012). Inspection of the concentrate samples after drying and weighing for the determination of grades and recoveries revealed that there was insufficient hydroxamate present on the sample to yield spectra with reliable data. However, samples investigated for $\mathrm{E}_{\mathrm{H}-\mathrm{pH}}$ studies did give good quality spectral data. In Fig. 15 the FT-IR and Raman spectra obtained from ground chrysocolla exposed to $1,200 \mathrm{~g} / \mathrm{t}$ AM2 for $2 \mathrm{~h}$ in a non stirred solution at $\mathrm{pH}$ 10, followed by washing with DDI water and air dried are shown. These spectra demonstrate that the AM2 has formed copper hydroxamate with the chrysocolla sample. There is no hydroxamic acid, potassium hydrogen 
hydroxamate or iron hydroxamate observable in the sample by these vibrational spectroscopic techniques, a result that shows that the pores of the chrysocolla do not adsorb substantial quantities of hydroxamate that is not copper hydroxamate. The signal-to-noise and intensity of the vibrational spectra obtained was consistent with the formation of multilayer copper hydroxamate. Vibrational spectroscopy is not surface sensitive, and could be sampling hydroxamate up to a micron below the surface of the sample.

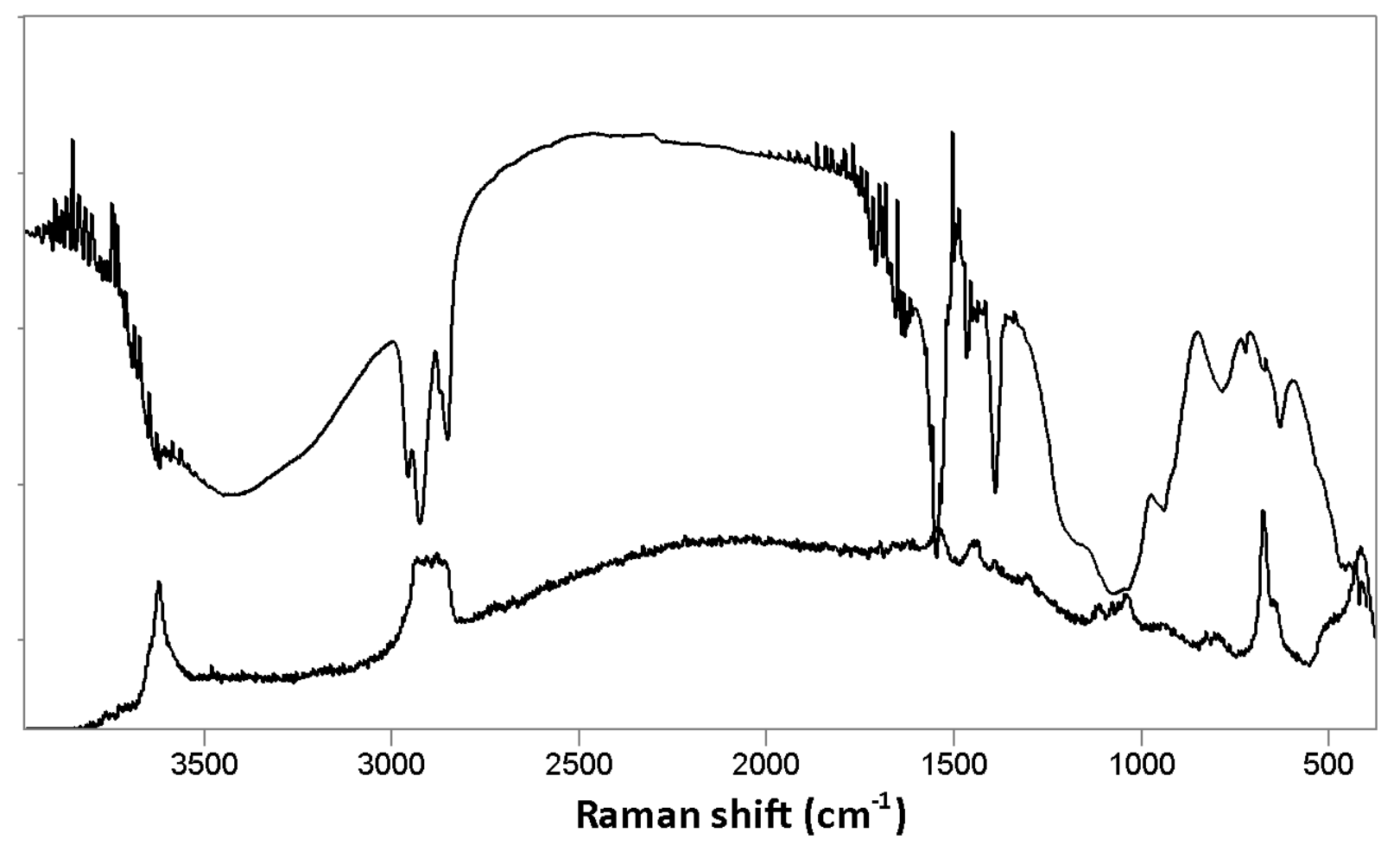

Fig. 15. Spectra from ground chrysocolla in $\mathrm{KBr}$ (FT-IR) (top) and a single particle (Raman), after exposure to AM2 at pH 10.

\section{Conclusions}

The bench-scale flotation of Clifton -chrysocolla and sand mixtures with AM2 hydroxamate collector using IF50 frother has yielded copper recoveries of over 97\% and copper grades that varied from close to the value measured for the bulk chrysocolla in the first flotation collection, to grades closer to half that value after a fourth collection. Copper recovery was only partially improved by the sequential additions of collector compared to a single dose while the grade achieved was slightly lower. Increased residence time of the collector in the pulp prior to flotation substantially degraded the recovery and lowered the grades collected. Magnetite was present as a gangue mineral in both the Clifton chrysocolla and Gosford sand used in the flotation experiments. The iron was collected at recoveries of up to $70 \%$, at grades of less than $7 \%$. The 
theoretical grade of pure magnetite is $72.4 \%$, so the flotation of magnetite does not achieve the relative grade levels observed for the chrysocolla.

XPS investigation of the first chrysocolla concentrate fraction collected at $\mathrm{pH} 6.5$ gave a reduced copper concentration $(\sim 5.5$ at $\%)$ at the surface of a particulate specimen compared to the value measured from an abraded surface of a sample prior to processing ( 14 at $\%)$. The measured surface composition of copper for the collected concentrate would be reduced due to any overlaying hydroxamate species, but the high Si concentration would indicate that the surface might have been leached of copper. The area sampled $(0.5$ $\mathrm{mm}$ ) during XPS analysis also could have contained silica gangue material. The surface nitrogen $1 s$ spectrum was consistent with copper hydroxamate contributing $85 \%$ of the signal with $15 \%$ attributable to hydroxamic acid. The value for the surface nitrogen concentration was high when the surface copper composition was considered.

Investigation of a mixed carbonate-chrysocolla-sand sample yielded higher grades and a faster $\mathrm{Cu}$ recovery, which would be expected from the higher initial copper grade attributable to the azurite and malachite. The XPS investigation found that for this sample, collected at $\mathrm{pH} 10$, the hydroxamate was present on the surface in a form consistent with copper n-octanohydroxamate, though significant levels of potassium were detected. Carbon (from carbonate) and associated copper were observed from the XPS data.

Vibrational spectra obtained from chrysocolla particles exhibited formation of copper hydroxamate following exposure to AM2 under flotation conditions, but no hydroxamic acid or AM2-like hydroxamate species were observed.

\section{Acknowledgements}

The Australian Research Council and Axis House have provided support for this research project. $\mathrm{Mr}$ Timothy Koo provided technical support for the flotation measurements undertaken at AMML.

\section{References}

Aplan, F.F., Fuerstenau, D.W., The flotation of crysocolla by mercaptan. International Journal of Mineral Processing, 1984, 13, 105-115. 
Barbaro, M., Herrera-Urbina, R., Cozza, C., Fuerstenau, D.W., Flotation of oxidized minerals of copper using a new systhetic reagent as collector. International Journal of Mineral Processing, 1997, 50, 275-287.

Fuerstenau, D.W., Herrera-Urbina, R., McGlashan, D.W., Studies on the applicability of chelating agents as universal collectors for copper minerals International Journal of Mineral Processing, 2000, 58, 15-33.

Fuerstenau, D.W., Pradip, 1984. Mineral flotation with hydroxamate collectors, In Reagents in Minerals Industry ed. M. J. Jones, R.O. Inst. Min. Met, London, pp. 161-168.

Herrera-Urbina, R., Laskowski, J., Fuerstenau, D.W., 2010. A process for the flotation of chrysocolla, In International mineral processing congress (IMPC) The Australasian Institue of Mining and Metallurgy, Brisbane, pp. 1959-1969.

Lee, J.S., Nagaraj, D.R., Coe, J.E., Practical aspects of oxide copper recovery with alkyl hydroxamates Minerals Engineering, 1998, 11, 929-939.

Lee, K., Archibald, D., McLean, J., Reuter, M.A., Flotation of mixed copper oxide and sulphide minerals with xanthate and hydroxamate collectors. Minerals Engineering, 2009, 22, 395-401.

Parker, G.K., Hope, G.A., Woods, R., Numprasanthai, A., Buckley, A.N., McLean, J., 2012. Investigation of the n Octanohydroxamate Reagent Interaction with the Surface of Oxide Copper Minerals and Copper Metal, In Yoon Symposium, 2011 SME Annual Meeting, ed. Young, C. SME, Denver, Colorado, p. Accepted $02 / 2011$.

Peterson, H.D., Fuerstenau, M.C., Rickard, R.S., Miller, J.D., Chrysocolla flotation by the formation of insoluble surface chelates. Transactions of the American Institute of Mining and Metallurgical Engineers, 1965, 232, 388-392.

RRUFF, 2011. Chrysocolla Raman, FT-IR and XRD reference data sets, http://rruff.info/Chrysocolla/R050053. 